\title{
Ring Contraction by NHC-Induced Pnictogen Abstraction
}

\author{
Martin Piesch ${ }^{+}$Stephan Reichl ${ }^{+}$, Michael Seidl $^{+}$, Gábor Balázs, and Manfred Scheer*
}

Dedicated to Prof. T. Don Tilley on the occasion of his $65^{\text {th }}$ birthday

Abstract: The reaction of $\left[C p^{\prime \prime \prime} C o\left(\eta^{4}-P_{4}\right)\right]$ (1) $\left(C p^{\prime \prime \prime}=1,2,4-\right.$

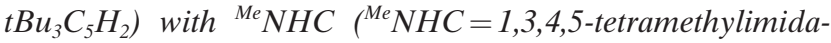
zol-2-ylidene) leads through NHC-induced phosphorus cation abstraction to the ring contraction product $\left[\left({ }^{\mathrm{Me}} \mathrm{NHC}\right)_{2} \mathrm{P}\right]-$ $\left[C p^{\prime \prime \prime} \mathrm{Co}\left(\eta^{3}-P_{3}\right)\right](2)$, which represents the first example of an anionic $\mathrm{CoP}_{3}$ complex. Such $\mathrm{NHC}$-induced ring contraction reactions are also applicable for triple-decker sandwich complexes. The complexes $\left[\left(C p^{*} M o\right)_{2}\left(\mu, \eta^{6: 6}-E_{6}\right)\right](3 \boldsymbol{a}, \mathbf{3} \boldsymbol{b})\left(C p^{*}=\right.$ $\left.\mathrm{C}_{5} \mathrm{Me}_{5} ; E=P, A s\right)$ can be transformed to the complexes $\left[\left({ }^{M e} \mathrm{NHC}\right)_{2} E\right]\left[\left(C p^{*} M\right)_{2}\left(\mu, \eta^{3: 3}-E_{3}\right)\left(\mu, \eta^{2: 2}-E_{2}\right)\right] \quad(\mathbf{4 a}, \mathbf{4 b})$, with $\mathbf{4 b}$ representing the first structurally characterized example of an NHC-substituted As $s^{I}$ cation. Further, the reaction of the vanadium complex $\left[\left(C p^{*} V\right)_{2}\left(\mu, \eta^{6: 6}-P_{6}\right)\right]$ (5) with ${ }^{M e} \mathrm{NHC}$ results in the formation of the unprecedented complexes $\left[\left({ }^{\mathrm{Me}} \mathrm{NHC}\right)_{2} \mathrm{P}\right]\left[\left(\mathrm{C} p^{*} \mathrm{~V}\right)_{2}\left(\mu, \eta^{6: 6}-\mathrm{P}_{6}\right)\right] \quad(\mathbf{6}), \quad\left[\left({ }^{\mathrm{Me}} \mathrm{NHC}\right)_{2} \mathrm{P}\right]-$ $\left[\left(C p^{*} V\right)_{2}\left(\mu, \eta^{5: 5}-P_{5}\right)\right] \quad$ (7) and $\left[\left(C p^{*} V\right)_{2}\left(\mu, \eta^{3: 3}-P_{3}\right)\left(\mu, \eta^{1: 1}-P\right.\right.$ $\left.\left.\left[{ }^{\mathrm{Me}} \mathrm{NHC}\right\}\right)\right](\mathbf{8})$.

$\boldsymbol{R}_{\text {ing contraction reactions are a powerful tool in organic }}$ synthesis, giving access to otherwise not, or only hardly accessible products. ${ }^{[1]}$ They can be divided into different groups, which are usually defined by the conditions that are required to induce the ring contraction (acidic, basic, oxidative, photolytic, and thermal). However, ring contraction reactions are not limited to carbocycles and heterocycles. ${ }^{[2]}$ For example, Stone et al. reported on the reaction of pentamethylcyclopentaphosphine $(\mathrm{MeP})_{5}$ with $\mathrm{CuCl}$ leading to the cyclotetraphosphine complex $(\mathrm{MeP}){ }_{4} \mathrm{CuCl}^{\left[{ }^{[3]}\right.} \mathrm{A}$ further example for ring contraction reactions involving cyclopolyphosphines was reported by Hey-Hawkins et al., the reaction of $\left(t \mathrm{Bu}_{4} \mathrm{P}_{5}\right)^{-}$with $\mathrm{SnCl}_{2}$ resulting in $\mathbf{A}$ (Scheme 1$){ }^{[4]}$ Thermally induced rearrangements are another method for ring contractions. For instance, this was shown for the formation of B (Scheme 1), which is obtained by heating a solution of $\left[\mathrm{Ni}\left(t \mathrm{Bu}_{4} \mathrm{P}_{5}\right)_{2}\right] \cdot{ }^{[5]}$ We recently found that the complexes $\left[(\mathrm{LCo})_{2}\left(\mu_{2}, \eta^{2: 2}-\mathrm{E}_{4}\right)\right] \quad\left(\mathrm{L}=\mathrm{CH}\{\mathrm{C}(\mathrm{Me}) \mathrm{N}(\mathrm{Dipp})\}_{2} ; \mathrm{E}=\mathrm{P}, \quad \mathrm{As}\right)$ undergo a thermally induced elimination of a pnictogen

[*] M. Piesch, ${ }^{[+]}$S. Reichl, ${ }^{[+]}$Dr. M. Seidl ${ }^{[+]}$Dr. G. Balázs, Prof. Dr. M. Scheer

Institute of Inorganic Chemistry, University of Regensburg 93040 Regensburg (Germany)

E-mail: manfred.scheer@chemie.uni-regensburg.de

Homepage: https://www.uni-regensburg.de/chemie-pharmazie/ anorganische-chemie-scheer

$\left.{ }^{+}\right]$These authors contributed equally to this work.

(2) Supporting information and the ORCID identification number(s) for (D) the author(s) of this article can be found under: https://doi.org/10.1002/anie.201908397. a)

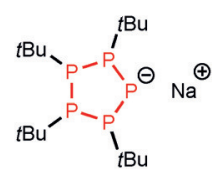

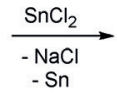

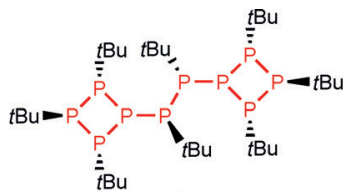

b)<smiles>CC(C)(C)CCCCC(C)(C)C</smiles>
A

c)

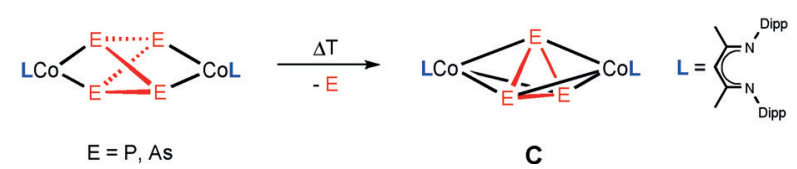

Scheme 1. Selected examples of ring contraction reactions of cyclopolyphosphines and polypnictogen ligand complexes.

atom leading to the triple-decker complexes $\left[(\mathrm{LCo})_{2}\left(\mu_{2}, \eta^{3: 3}\right.\right.$ $\left.\left.\mathrm{E}_{3}\right)\right](\mathbf{C})$ with an $\mathrm{E}_{3}$ middle deck. ${ }^{[6]}$

This insight raised the question if there might be a general and more selective way avoiding harsh reaction conditions to promote ring contraction reactions to be used for the synthesis of new and otherwise not accessible compounds. In the case of polypnictogen compounds, this would lead to more desirable compounds in terms of functionalization or synthesis of organophosphorus compounds. ${ }^{[7]}$ Here, the thermally induced ring contractions are limited to only few polypnictogen ligand complexes. Their outcome is not predictable and combined with low yields. Therefore, in our opinion, the use of $\mathrm{N}$-heterocyclic carbenes $(\mathrm{NHCs})^{[7 \mathrm{~d}, 8]}$ seemed to be a promising approach. It was shown by Bertrand that NHCs or cyclic (alkyl)-(amino)carbenes (CAACs) can be reacted with white phosphorus $\left(\mathrm{P}_{4}\right)$, leading to $\mathrm{P}_{4}$ species ${ }^{[9]}$ fragmented into a bis(NHC)-supported $\mathrm{P}^{\mathrm{I}}$ cation and a formal NHC-coordinated $\mathrm{P}_{3}^{-}$unit, or by aggregation to an NHCsubstituted $\mathrm{P}_{12}$ cage compound, ${ }^{[10]}$ depending on the used carbene and stoichiometry. The NHC-coordinated $\mathrm{P}_{3}{ }^{-}$unit could only be monitored by ${ }^{31} \mathrm{P}$ NMR spectroscopy. ${ }^{[\mathrm{b}]}$ Other examples for an NHC-induced phosphorus atom abstraction from cyclo-pnictines, $\mathrm{P}_{4}, \mathrm{P}_{7}{ }^{3-}$ and other polyphosphorus cages were described, ${ }^{[11]}$ but did not feature a ring contraction. Weigand et al. reported on a degradation of a cationic $\mathrm{P}_{5}$ cage into an allylic $\mathrm{P}_{3}$ and a $\mathrm{P}_{2}$ unit substituted by NHCs. ${ }^{[1 \mathrm{e}]}$ Herein, we report a general method for ring contraction reactions induced by the NHC-assisted abstraction of a pnictogen cation for a large variety of polypnictogen complexes, 
leading to unprecedented and otherwise not accessible complexes.

We recently showed that $\left[\mathrm{Cp}^{\prime \prime \prime} \mathrm{Co}\left(\eta^{4}-\mathrm{P}_{4}\right)\right](\mathbf{1})^{[12]}$ can be used for ring expansion reactions with the pentelidene complexes $\left[\mathrm{Cp} * \mathrm{E}\left\{\mathrm{W}(\mathrm{CO})_{5}\right\}_{2}\right](\mathrm{E}=\mathrm{P}, \mathrm{As}) .{ }^{[13]}$ The release of ring strain might be the driving force of such reactions, leading to a five-membered ring system. It was a challenge to investigate if $\mathbf{1}$ is also a candidate for a ring contraction reaction by increasing the ring strain.

The addition of ${ }^{\mathrm{Me}} \mathrm{NHC}$ to a solution of $\mathbf{1}$ at $-80^{\circ} \mathrm{C}$ resulted in an immediate colour change, which is completed at room temperature. After workup, $\left[\left({ }^{\mathrm{Me}} \mathrm{NHC}\right)_{2} \mathrm{P}\right]\left[\mathrm{Cp} \mathrm{p}^{\prime \prime \prime} \mathrm{Co}\left(\eta^{3}-\right.\right.$ $\left.\mathrm{P}_{3}\right)$ ] (2) was isolated in a crystalline yield of $79 \%$ (Scheme 2).

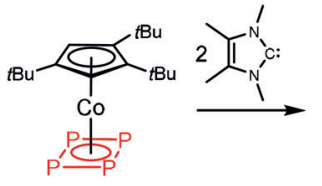

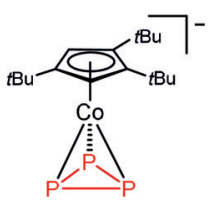

Scheme 2. Reaction of $\left[\mathrm{Cp}^{\prime \prime \prime} \mathrm{Co}\left(\eta^{4}-\mathrm{P}_{4}\right)\right](1)$ with ${ }^{\mathrm{Me}} \mathrm{NHC}$.

The ${ }^{31} \mathrm{P}$ NMR spectrum of the reaction mixture showed only two singlets, one at $-111.4 \mathrm{ppm}$ for the $\left[\left({ }^{\mathrm{Me}} \mathrm{NHC}\right)_{2} \mathrm{P}\right]^{+}$cation and one at $-313.3 \mathrm{ppm}$ for the $\left[\mathrm{Cp}^{\prime \prime \prime} \mathrm{Co}\left(\eta^{3}-\mathrm{P}_{3}\right)\right]^{-}$anion, indicating a full conversion of the starting compounds to 2 . Compound $\mathbf{2}$ is formed by an NHC-induced phosphorus abstraction, leading to a bis( $\mathrm{NHC})$-coordinated $\mathrm{P}^{\mathrm{I}}$ cation and the ring contraction product $\left[\mathrm{Cp}^{\prime \prime \prime} \mathrm{Co}\left(\eta^{3}-\mathrm{P}_{3}\right)\right]^{-}$. The latter is the first representative of an anionic $\mathrm{CoP}_{3}$ complex, revealing a cyclo- $\mathrm{P}_{3}$ end-deck. The tetrahedral $\mathrm{CoP}_{3}$ unit (Figure 1) is

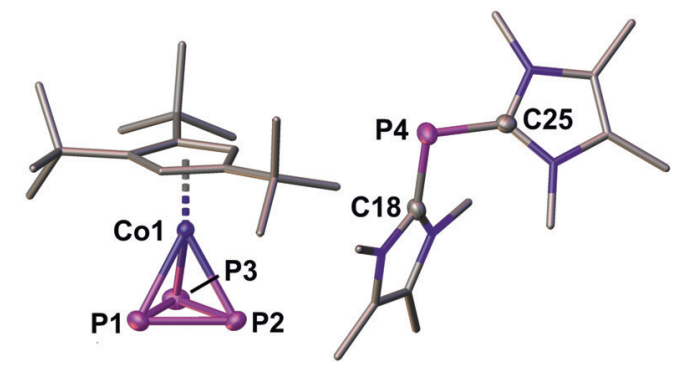

Figure 1. Molecular structure of 2 with thermal ellipsoids at $50 \%$ probability level. Hydrogen atoms and solvent molecules are omitted for clarity. ${ }^{[22]}$

formally isolobal to $\mathrm{P}_{4}$ in which one phosphorus atom is replaced by a $15 \mathrm{VE} \mathrm{Cp}^{\prime \prime \prime} \mathrm{Co}^{-}$fragment. The Mulliken population analysis performed on the optimized geometry of $\left[\mathrm{Cp}^{\prime \prime \prime} \mathrm{Co}\left(\eta^{3}-\mathrm{P}_{3}\right)\right]^{-}$shows that the negative charge is mostly located on the $\mathrm{P}_{3}$ unit $(-0.64)$ and considerably less on the $\mathrm{Cp}^{\prime \prime \prime}$ ligand $(-0.12)$ and at the Co atom as well $(-0.26)$. The $\mathrm{P}-\mathrm{P}$ and $\mathrm{Co}-\mathrm{P}$ bond lengths are between 2.1552(6) $\AA$ and 2.1624(6) $\AA$ and between 2.2596(5) $\AA$ and 2.2705(5) $\AA$, respectively, and therefore in the range of single bonds. These distances differ slightly from the recently reported neutral complex $\left[\left\{\mathrm{CNAr}{ }^{\mathrm{Mes} 2}\right\}_{3} \mathrm{Co}\left(\eta^{3}-\mathrm{P}_{3}\right)\right]\left(\mathrm{Ar}^{\mathrm{Mes} 2}=2,6-(2,4,6-\right.$
$\left.\mathrm{Me}_{3} \mathrm{C}_{6} \mathrm{H}_{2}\right)_{2} \mathrm{C}_{6} \mathrm{H}_{3}$ ) for which the $\mathrm{Co}-\mathrm{P}$ bond lengths are somewhat elongated with 2.312(1) $\AA$ to 2.317(1) $\AA^{[14]}$

Since we were interested in the elucidation of the reaction pathway between $\mathbf{1}$ and ${ }^{\mathrm{Me}} \mathrm{NHC}$, we performed a temperature-depending ${ }^{31} \mathrm{P} N \mathrm{NM}$ study, ranging from $-80^{\circ} \mathrm{C}$ to room temperature (in $20^{\circ} \mathrm{C}$ steps). The spectra show several signal sets indicating the formation of different intermediates. Unfortunately, an identification of these intermediates was not possible and even numerous attempts to isolate them at low temperature failed. Nevertheless, after 18 hours at room temperature, the ${ }^{31} \mathrm{P}$ NMR spectrum of the reaction mixture shows only the signals of $\mathbf{2}$ (see Figure S4, Supporting Information).

Since the desired $\mathrm{P}_{n}$ ring contraction was successful for sandwich complexes such as $\mathbf{1}$, we were interested to find out if the novel concept is applicable to triple-decker sandwich complexes containing polypnictogen middle decks $(E=P$, As). The release of an atom in these compounds is much hindered and thus, particularly challenging. The triple-decker $\left[\{\mathrm{Cp} * \mathrm{Mo}\}_{2}\left(\mu, \eta^{6: 6}-\mathrm{P}_{6}\right)\right](\mathbf{3 a})$ was reacted with 2 equivalents of

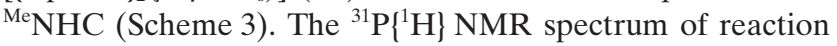
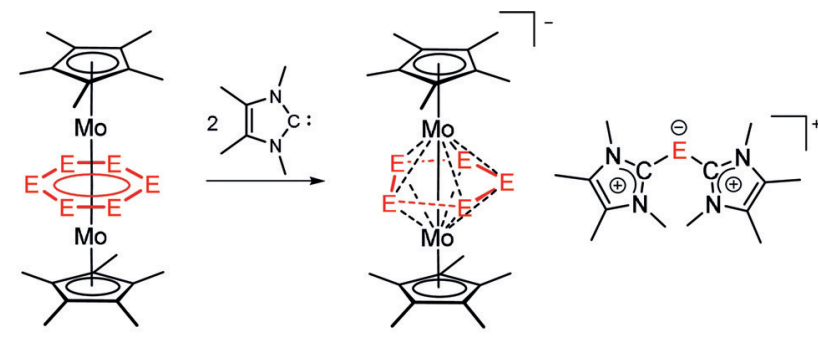

3a: $E=P ; 3 b: E=A s$

4a: $E=P ; 4 b: E=A s$

Scheme 3. Reaction of $\left[\left\{C p^{*} \mathrm{Mo}_{2}\left(u, \eta^{6: 6}-\mathrm{E}_{6}\right)\right](\mathrm{E}=\mathrm{P}(\mathbf{3} \mathrm{a})\right.$, As $(3 \mathrm{~b}))$ with ${ }^{\mathrm{Me}} \mathrm{NHC}$.

mixtures only showed two singlets at $-112.4 \mathrm{ppm}$ and $-59.9 \mathrm{ppm}$, indicating a full conversion of the starting complex $\mathbf{3 a}$ to a bis(NHC)-supported $\mathrm{P}^{\mathrm{I}}$ cation $(-112.4 \mathrm{ppm})$ and the anticipated anion $\left[\left\{\mathrm{Cp}^{*} \mathrm{Mo}_{2}\left(\mu, \eta^{5: 5}\right.\right.\right.$ $\left.\left.\mathrm{P}_{5}\right)\right]^{-}$(Scheme 3). After workup, 4a was isolated in $49 \%$ crystalline yield as dark green blocks. The molecular structure of $4 \mathbf{a}$ (see Figure $\mathrm{S} 19 / 20$ ) shows a $\mathrm{P}_{5}$ middle deck disordered over two positions (60:40), with shorter (2.313(19) $\AA$-2.480(12) $\AA$ ) and longer (2.500(10) $\AA-2.605(11) \AA)$ P...P distances. The latter might best be described as separated $\mathrm{P}_{3}$ and $\mathrm{P}_{2}$ units instead of a cyclo- $\mathrm{P}_{5}$ middle deck. This geometry is also confirmed by DFT calculations, which reproduce the experimental geometric parameters of the anion in $\mathbf{4 a}$ well (see Supporting Information). The Wiberg bond indices (WBIs) for the longer P...P distances indicate with 0.13 only weak interactions. The WBIs of the shorter $\mathrm{P}-\mathrm{P}$ distances amount to 1.16 for the $\mathrm{P}_{2}$ unit and 0.82 for the $\mathrm{P}_{3}$ unit. Very surprisingly, even at $-80^{\circ} \mathrm{C}$ only one slightly broadened singlet centered at $-62.9 \mathrm{ppm}$ was observed in the ${ }^{31} \mathrm{P}$ $\left\{{ }^{1} \mathrm{H}\right\}$ NMR spectrum in solution, as it is anticipated for a symmetrical $\mathrm{P}_{5}$ middle deck. This result points to a fast rearrangement on the NMR timescale of the distorted $\mathrm{P}_{5}$ middle deck, as observed in solid state, to a symmetric cyclo- 
$\mathrm{P}_{5}$ unit in solution, even at low temperatures. This process probably occurs through a simultaneous $\mathrm{P}-\mathrm{P}$ bond formation/ bond cleavage reaction. The $\mathrm{Mo}-\mathrm{Mo}$ bond distance of 2.667(1) $\AA$ is in the range of a single bond, which is in accordance with the WBI of 0.70 . Complex $4 \mathbf{a}$ is the first example of a molybdenum triple-decker complex containing a $\mathrm{P}_{5}$ middle deck. Usually the co-thermolysis of $\left[\mathrm{Cp}^{\mathrm{R}} \mathrm{M}\right.$ $\left.(\mathrm{CO})_{3}\right]_{2}$ with $\mathrm{P}_{4}$ affords for $\mathrm{M}=\mathrm{Mo}, \mathrm{W}$ the cyclo- $\mathrm{P}_{6}$ tripledecker complexes, such as $\mathbf{3 a}$. Only for $\mathrm{M}=\mathrm{Cr}$, the neutral complex $\left[(\mathrm{Cp} * \mathrm{Cr})_{2}\left(\mu, \eta^{5: 5}-\mathrm{P}_{5}\right)\right]^{[15]}$ is obtained. Although, the structure of the latter was verified crystallographically, the quality of the reported X-ray data does not allow the discussion of bond distances.

Complex $\left[\left\{\mathrm{Cp} * \mathrm{Mo}_{2}\left(\mu, \eta^{6: 6}-\mathrm{As}_{6}\right)\right](\mathbf{3} \mathbf{b})\right.$, which is the heavier homologue of $\mathbf{3 a}$, was also reacted with 2 equivalents of ${ }^{\mathrm{Me}} \mathrm{NHC}$ to investigate if the pnictogen abstraction observed for $\mathbf{3 a}$ is also possible in the case of a polyarsenic ligand. This reaction proceeds analogously to the phosphorus complex and, after workup, the product $\left[\left({ }^{\mathrm{Me}} \mathrm{NHC}\right)_{2} \mathrm{As}\right]-$ $\left[\{\mathrm{Cp} * \mathrm{Mo}\}_{2}\left(\mu, \eta^{5: 5}-\mathrm{As}_{5}\right)\right]$ (4b) was isolated as dark green blocks in $82 \%$ yield. The cation $\left[\left({ }^{\mathrm{Me}} \mathrm{NHC}\right)_{2} \mathrm{As}\right]^{+}$within $\mathbf{4 b}$ is the first structurally characterized example of a doubly NHCsubstituted $\mathrm{As}^{\mathrm{I}}$ cation and the second known in literature. ${ }^{[8,16]}$ Interestingly, the only other example was reported by Märkl et al., describing the reaction of 2-chlor-N-methyl-benzthiazolium-tetrafluoroborat with $\mathrm{As}\left(\mathrm{SiMe}_{3}\right)_{3} \cdot{ }^{[17]}$ The molecular structure of $\mathbf{4 b}$ is shown in Figure 2. The As $-\mathrm{C}$ bond distances
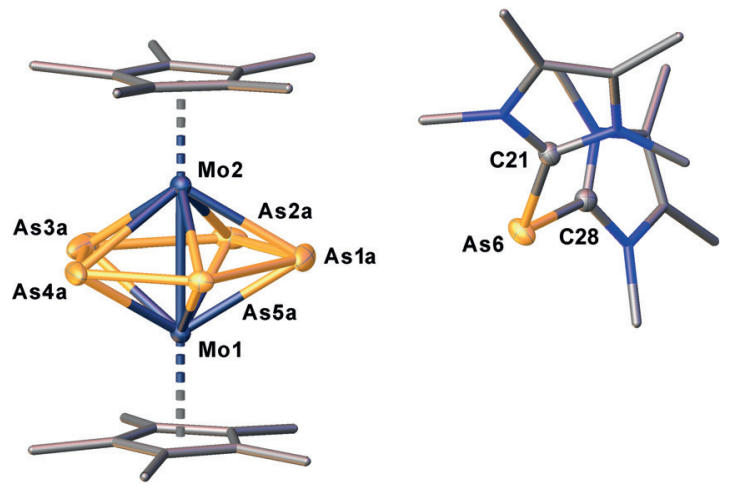

Figure 2. Molecular structure of $\mathbf{4 b}$ (for $\mathbf{4}$ a see Supporting Information) with thermal ellipsoids at $50 \%$ probability level. Only the main part of the disordered $\mathrm{As}_{5}$ middle deck is depicted. Hydrogen atoms and solvent molecules are omitted for clarity. ${ }^{[22]}$

for the cation $\left[\left({ }^{\mathrm{Me}} \mathrm{NHC}\right)_{2} \mathrm{As}\right]^{+}$of $1.924(2) \AA$ and $1.927(2) \AA$ are in the range of single bonds. These distances are predictable for an $\mathrm{C}-\mathrm{As}-\mathrm{C}-\mathrm{N}$ torsion angle of about $43^{\circ}$, which prevents an effective overlap of the $\pi$-system on the NHC fragments with the $p$ orbitals on As. ${ }^{[18]}$ As for the anionic part, although the $\mathrm{As}_{5}$ middle deck is disordered over three positions with occupations of 0.62 to 0.26 to 0.12 (see Supporting Information), one can again distinguish between shorter (2.289(14) $\AA$ to 2.463(4) $\AA$ ) and longer (2.729(15) $\AA$ to $2.870(13) \AA$ ) As $\cdots$ As distances (similar to $4 \mathbf{a}$ ). Therefore, the $\mathrm{As}_{5}$ middle deck is also best described as separate $\mathrm{As}_{3}$ and $\mathrm{As}_{2}$ ligands instead of a cyclo-As $s_{5}$ ligand, which is in accordance to DFT calculations (cf. Supporting Information).
The neutral complex $\left[\{\mathrm{CpMo}\}_{2}\left(\mu, \eta^{5: 5}-\mathrm{As}_{5}\right)\right]$, which was obtained by Rheingold et al. from co-thermolysis of [CpMo$\left.(\mathrm{CO})_{3}\right]_{2}$ with $(\mathrm{MeAs})_{5}$, also features two long and three short As $\cdots$ As distances. However, the Mo-Mo bond of 2.764(2) $\AA$ is slightly longer than for $\mathbf{4 b}$ as an anion. The As-As bond length of the $\mathrm{As}_{2}$ unit of 2.570(2) $\AA$ is longer by 0.183 or $0.281 \AA$, respectively, compared to As-As bond in $4 \mathbf{b}$. Additionally, the long As $\cdots$ As distances are shorter. These differences become more distinct by comparing the bond distances of the optimized structures of both complexes (cf. Supporting Information).

The complex $\left[\{\mathrm{Cp} * \mathrm{~V}\}_{2}\left(\mu, \eta^{6: 6}-\mathrm{P}_{6}\right)\right](5)$ is one of only a few examples for vanadium complexes containing polyphosphorus ligands. ${ }^{[19]}$ So far, no vanadium triple-decker complex with a $\mathrm{P}_{5}$ middle deck is known. 5 was reacted with ${ }^{\mathrm{Me}} \mathrm{NHC}$ to induce the anticipated ring contraction, leading to the desired complex $\left[\left({ }^{\mathrm{Me}} \mathrm{NHC}\right)_{2} \mathrm{P}\right]\left[\{\mathrm{Cp} * \mathrm{~V}\}_{2}\left(\mu, \eta^{5: 5}-\mathrm{P}_{5}\right)\right] \quad$ (7) (Scheme 4).

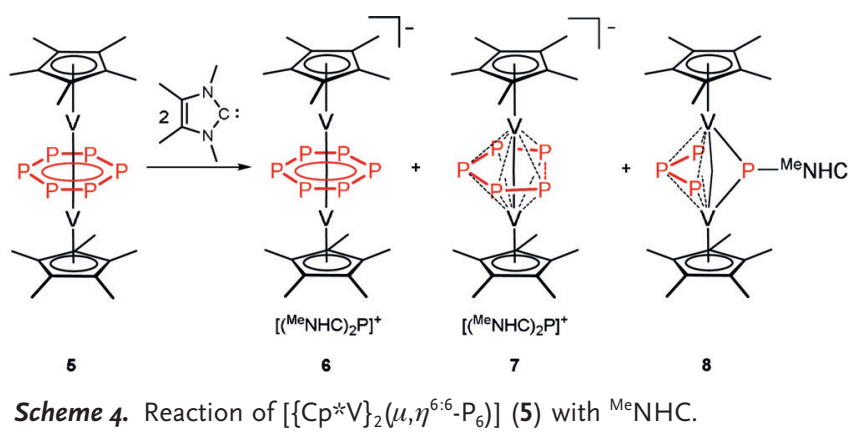

However, the reaction did not solely result in $\mathbf{7}$, additionally the two complexes $\left[\left({ }^{\mathrm{Me}} \mathrm{NHC}\right)_{2} \mathrm{P}\right]\left[\{\mathrm{Cp} * \mathrm{~V}\}_{2}\left(\mu, \eta^{6: 6}-\mathrm{P}_{6}\right)\right](\mathbf{6})$ and $\left[\{\mathrm{Cp} * \mathrm{~V}\}_{2}\left(\mu, \eta^{3: 3}-\mathrm{P}_{3}\right)\left(\mu-\mathrm{P}^{\mathrm{Me}} \mathrm{NHC}\right)\right](\mathbf{8})$ were obtained. Complex $\mathbf{6}$ is probably formed by reduction of the starting compound $\mathbf{5}$. In contrast, the formation of $\mathbf{8}$ seems to involve several indistinct reaction steps. The formation of $\mathbf{8}$ also reveals that the applied method can be even used to go further by abstracting more than one pnictogen atom (for a possible mechanism see Supporting Information). By monitoring this reaction by ${ }^{31} \mathrm{P}\left\{{ }^{1} \mathrm{H}\right\}$ NMR at variable temperatures $\left(20^{\circ} \mathrm{C}\right.$ steps, starting from $-80^{\circ} \mathrm{C}$ to r.t.), we tried to get insights into some of the reaction processes involved (Figure S17). At low temperatures, only two broad signals at about $320 \mathrm{ppm}$ and $238 \mathrm{ppm}$ are observed next to the signal of the cation $\left[\left({ }^{\mathrm{Me}} \mathrm{NHC}\right)_{2} \mathrm{P}\right]^{+}$of 7 . The signals merge into one broad signal at $280 \mathrm{ppm}$ at room temperature. After two days, this signal vanished completely and only the signals for the cation $\left[\left({ }^{\mathrm{Me}} \mathrm{NHC}\right)_{2} \mathrm{P}\right]^{+}$and the products $\mathbf{7}$ and $\mathbf{8}$ were present. Unfortunately, these observations did not contribute to the identification of intermediates involved in the reaction pathway. Since $\mathbf{8}$ is a neutral complex, it can easily be separated from the ionic complexes $\mathbf{6}$ and $\mathbf{7}$ by extraction of the crude reaction residue with toluene (isolated yield of 8: $18 \%$ ). However, separation of $\mathbf{6}$ and $\mathbf{7}$ is not possible, since both complexes only differ in the nature of the $\mathrm{P}_{n}$ middle deck, resulting in similar solubility. Moreover, it was not possible to separate both compounds by fractionated crystallisation, since both compounds co-crystallise (isolated yield of $\mathbf{6}$ and 
7: $49 \%$ ). Increasing the amount of the used ${ }^{\mathrm{Me}} \mathrm{NHC}$ from 2 to 3 equivalents is leading to an increased formation of $\mathbf{8}$ (isolated yield $24 \%$ ). Further increase to 6 equivalents of ${ }^{\mathrm{Me}} \mathrm{NHC}$, however, results in the formation of not identified products

The molecular structures of $\mathbf{6}$ and $\mathbf{7}$ are depicted in Figure 3. For clarity, the overlaying middle decks are shown as a)

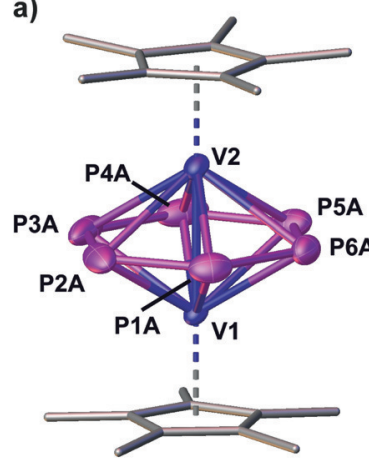

b)

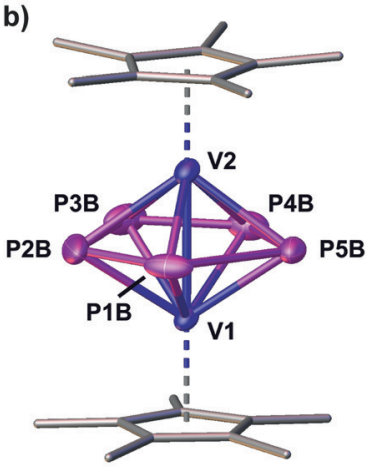

Figure 3. Molecular structure of the anionic part of compound 6 (a) and 7 (b) with thermal ellipsoids at $50 \%$ probability level. Hydrogen atoms and solvent molecules are omitted for clarity. ${ }^{[2]}$

separated molecules. The distribution of the disordered middle decks was found to be 0.6 for the planar cyclo- $\mathrm{P}_{6}$ unit of 6 and 0.4 for the planar cyclo- $\mathrm{P}_{5}$ unit of 7. A similar distribution was found by elemental analysis of the crystals. For both compounds, the $\mathrm{Cp}^{*}$ ligands and the middle deck are nearly oriented in parallel. The $\mathrm{P}-\mathrm{P}$ bond distances of 2.139(4) $\AA$ to 2.161(3) $\AA$ in $\mathbf{6}$ are all very similar and are in the range between single and double bonds. The $\mathrm{V} \cdots \mathrm{V}$ distance of 2.6766(6) $\AA$ is in the range of a single bond. ${ }^{[20]}$ However, the optimized geometries (B3LYP/def2-SVP level of theory) obtained for the anion in $\mathbf{6}$ differ slightly from those obtained experimentally. With $2.585 \AA$, the $\mathrm{V}-\mathrm{V}$ bond is shorter and the $\mathrm{P}-\mathrm{P}$ distances are no longer equal and can be divided in four shorter $(2.149 \AA-2.151 \AA)$ and two longer (2.283 $\AA$ and $2.287 \AA$ ) $\mathrm{P}-\mathrm{P}$ distances, featuring a bis-allylic distortion of the six-membered polyphosphorus middle deck. The X-ray structure of $\mathbf{7}$ shows four short $\mathrm{P}-\mathrm{P}$ distances in the range of single bonds (2.193(6) $\AA$ to 2.239(7) $\AA$ ) and one long $\mathrm{P}$...P distance of 2.677(7) $\AA$, which is too long for a $\mathrm{P}-\mathrm{P}$ bond, featuring an open $\mathrm{P}_{5}$ chain as middle deck. As for 6, experimentally obtained structural parameters of $\mathbf{7}$ differ from the geometry optimized by DFT (B3LYP/def2-SVP level of theory). One difference is that the $\mathrm{Cp}^{*}$ ligands are no longer parallel for the DFT-optimized structure. The second, more obvious difference is found at the middle deck. Since the $\mathrm{P}_{5}$ ligand is no longer planar, one phosphorus atom is bent out of the plane (dihedral angle of about $140^{\circ}$ ) (cf. Supporting Information). These discrepancies between the DFT-optimized geometries (gas phase) and the experimentally determined structural parameters of the two complexes $\mathbf{6}$ and $\mathbf{7}$ might be caused by multiple additional weak interactions in the solid state, especially since $\mathbf{6}$ co-crystallizes together with 7. Compound $\mathbf{7}$ is a diamagnetic $26 \mathrm{VE}$ (valence electron) species and shows a broad signal at $611.7 \mathrm{ppm}$ for the $\mathrm{P}_{5}$ middle deck in the ${ }^{31} \mathrm{P}\left\{{ }^{1} \mathrm{H}\right\}$ NMR spectrum next to the signals for the $\left[\left({ }^{\mathrm{Me}} \mathrm{NHC}\right)_{2} \mathrm{P}\right]^{+}$cation, and a singlet at $2.34 \mathrm{ppm}$ in the ${ }^{1} \mathrm{H}$ NMR spectrum for the Cp* ligands. Regarding the acycliclike $\mathrm{P}_{5}$ middle deck, three signals in the ${ }^{31} \mathrm{P}$ NMR are expected. However, only one singlet at $611.7 \mathrm{ppm}$ is observed, even if the solution is cooled to $-80^{\circ} \mathrm{C}$, indicating a fast dynamic rearrangement on the NMR timescale (cf. Figure S13). In contrast to 7, compound 6 represents a paramagnetic $27 \mathrm{VE}$ species, which is confirmed in both, the solid state and in solution, by a broad EPR signal at $g_{\text {iso }} \approx 2.014$ (see Figure S12) at $77 \mathrm{~K}$ (recorded from the mixture of 6 and 7). In the ${ }^{31} \mathrm{P}\left\{{ }^{1} \mathrm{H}\right\}$ NMR only the signal for the diamagnetic cation $\left[\left({ }^{\mathrm{Me}} \mathrm{NHC}\right)_{2} \mathrm{P}\right]^{+}$is detected at $-110.9 \mathrm{ppm}$. In the ${ }^{1} \mathrm{H} \mathrm{NMR}$ spectrum, only one broad signal for the $\mathrm{Cp}^{*}$ ligands at $0.95 \mathrm{ppm}$ is identified, next to the signal of the cationic part (singlets at $2.23 \mathrm{ppm}$ and $3.50 \mathrm{ppm}$ ).

It was also possible to obtain crystals (red rods) of $\mathbf{8}$ from a thf solution layered with hexane (Figure 4). The Cp* ligands and the $\mathrm{P}_{4}$ middle deck are both planar and parallel. The $\mathrm{V}-\mathrm{V}$

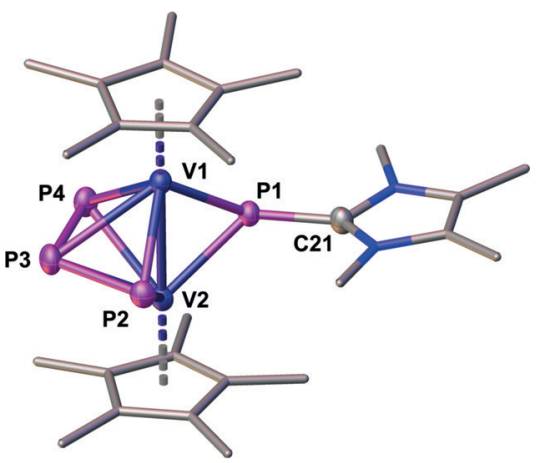

Figure 4. Molecular structure of compound 8 with thermal ellipsoids at $50 \%$ probability level. Hydrogen atoms and solvent molecules are omitted for clarity. ${ }^{[22]}$

bond distance of 2.6375(8) $\AA$ is in a similar range as observed for 6 and 7. The $\mathrm{P}-\mathrm{P}$ distances for $\mathrm{P} 2-\mathrm{P} 3$ and $\mathrm{P} 3-\mathrm{P} 4$ of 2.159(1) $\AA$ and 2.134(1) $\AA$, respectively, are in the range between a single and a double bond, featuring an allylic $\mathrm{P}_{3}$ ligand. The distances between $\mathrm{P} 1-\mathrm{P} 2$ and $\mathrm{P} 1-\mathrm{P} 4$ of $3.467-$ (1) $\AA$ and 3.144(1) $\AA$, respectively, are far too long for any interactions. This is also in accordance with the calculated optimized geometries of $\mathbf{8}$ (B3LYP/def2-SVP level of theory) and the WBI's of 0.04 and 0.05 , respectively. Interestingly, the remaining $\mathrm{NHC}-\mathrm{P}$ unit in $\mathbf{8}$ can be regarded as an NHCphosphinidenide ligand bridging the two vanadium atoms. In the literature, only a few transition metal complexes with such NHC-phosphinidenide ligands are known. ${ }^{[21]}$ In Figure 5, two

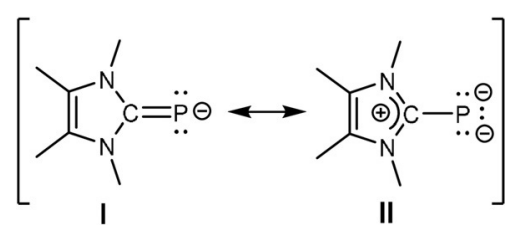

Figure 5. Resonance structures (I, II) of the NHC-phosphinidenide ligand. 
possible resonance structures (I and II) for such NHCphosphinidenide ligands are shown. The $\mathrm{P}-\mathrm{C}$ bond length of 1.804(4) $\AA$, which is in the region of a single bond, indicates that resonance structure II contributes mainly to the experimentally observed structure of $\mathbf{8}$. This is also in agreement with other known NHC-phosphinidenide complexes with $\mathrm{P}-$ C bonds between 1.797(3) $\AA$ and 1.824(2) $\AA^{\left[{ }^{[21 a, c, d]}\right.}$ Only the mercury complex $\left[\left({ }^{\text {Dipp }} \mathrm{NHC}=\mathrm{P}\right)_{2} \mathrm{Hg}\right]$ reported by Grützmacher et al. features a shorter $\mathrm{P}-\mathrm{C}$ bond (1.754(6) $\AA$ ), indicating a higher contribution of the resonance structure I. ${ }^{[21 \mathrm{~b}]}$

The ${ }^{31} \mathrm{P}\left\{{ }^{1} \mathrm{H}\right\}$ NMR spectrum of $\mathbf{8}$ shows three different signals at $659.4,446.1$ and $-8.7 \mathrm{ppm}$, being in accordance with values calculated for the chemical shifts (cf. Supporting Information). The signals originating from the $\mathrm{P}_{3}$ unit are observed at $659.4 \mathrm{ppm}$ as a broad doublet with a coupling constant of $427 \mathrm{~Hz}$ and as a sharp triplet of doublets at $-8.7 \mathrm{ppm}\left({ }^{1} J_{\mathrm{P}, \mathrm{P}}=427 \mathrm{~Hz} ;{ }^{2} J_{\mathrm{P}, \mathrm{P}}=38 \mathrm{~Hz}\right)$. The broad signal at $446.1 \mathrm{ppm}$ is originating from the NHC- $\mathrm{P}_{1}$ unit, which is in a similar region as the NHC-phosphinidenide complexes reported by Tamm et al. ${ }^{[1 \mathrm{a}, \mathrm{c}]}$ The broadening of the signals may be explained by a dynamic rearrangement of this NHCsubstituted $\mathrm{P}_{1}$ unit. This would also explain why only the two outer phosphorus atoms show a broadening of the ${ }^{31} \mathrm{P}$ NMR signal for the $\mathrm{P}_{3}$ unit. Cooling the solution to $-80^{\circ} \mathrm{C}$ does not lead to four separated ${ }^{31} \mathrm{P}$ NMR resonances. However, a sharpening and a shift of the doublet to $645.4 \mathrm{ppm}$ can be monitored (see Figure S16).

In conclusion, we showed that ring contraction reactions can be induced by NHCs to extrude a pnictogen cation from cyclo- $\mathrm{P}_{n}$ and cyclo-As ${ }_{n}$ ligands of sandwich and triple-decker sandwich complexes. This novel and general method is working under very mild conditions and can be used to generate unprecedented complexes, which could otherwise not be obtained. Following this method, three new vanadium triple-decker complexes with polyphosphorus middle decks, unprecedented triple-decker complexes of Mo with a cyclo- $\mathrm{E}_{5}$ unit and, most important, an unprecedented anionic $\mathrm{CoP}_{3}$ complex were accessible for the first time. Future investigations will focus on examining the reaction pathway of such abstraction reactions by isolation of the intermediates. This might become feasible, if different NHCs are used. Another promising goal is the use of other low-valent main group compounds for such pnictogen atom abstraction reactions, such as CAACs or silylenes.

\section{Acknowledgements}

This work was supported by the Deutsche Forschungsgemeinschaft (DFG) within the project Sche 384/38-1.

\section{Conflict of interest}

The authors declare no conflict of interest.
Keywords: arsenic c carbenes - phosphorus - ring contraction . vanadium

How to cite: Angew. Chem. Int. Ed. 2019, 58, 16563-16568 Angew. Chem. 2019, 131, 16716-16721

[1] a) "Carbocyclic Ring Contraction Reactions": D. Redmore, C. D. Gutsche, Advances in Alicyclic Chemistry, Vol. 3, (Ed. H. Hart, G. J. Karabatsos), Academic Press, New York, 1971, pp. 1 138; b) M. Bohle, J. Liebscher, Advances in Heterocyclic Chemistry, Vol. 65 (Ed.: A. R. Katritzky), Elsevier, Amsterdam, 1996, pp. 39-92; c) L. F. Silva, Tetrahedron 2002, 58, 9137 -9161; d) L. Silva, Synlett 2014, 25, 466-476; e) S. A. Snyder, E. J. Corey, J. Am. Chem. Soc. 2006, 128, 740-742; f) Y. Kita, K. Higuchi, Y. Yoshida, K. Iio, S. Kitagaki, K. Ueda, S. Akai, H. Fujioka, J. Am. Chem. Soc. 2001, 123, 3214-3222.

[2] a) M. Baudler, K. Glinka, Chem. Rev. 1993, 93, 1623-1667; b) S. S. Chitnis, H. A. Sparkes, V. T. Annibale, N. E. Pridmore, A. M. Oliver, I. Manners, Angew. Chem. Int. Ed. 2017, 56, 95369540; Angew. Chem. 2017, 129, $9664-9668$.

[3] C. S. Cundy, M. Green, F. G. A. Stone, A. Taunton-Rigby, J. Chem. Soc. A 1968, 1776.

[4] A. Schisler, P. Lönnecke, T. Gelbrich, E. Hey-Hawkins, Dalton Trans. 2004, 2895.

[5] S. Gómez-Ruiz, A. Schisler, P. Lönnecke, E. Hey-Hawkins, Chem. Eur. J. 2007, 13, 7974.

[6] a) F. Spitzer, G. Balázs, C. Graß1, M. Keilwerth, K. Meyer, M. Scheer, Angew. Chem. Int. Ed. 2018, 57, 8760; Angew. Chem. 2018, 130, 8896; b) F. Spitzer, C. Graßl, G. Balázs, E. Mädl, M. Keilwerth, E. M. Zolnhofer, K. Meyer, M. Scheer, Chem. Eur. J. 2017, 23, 2716.

[7] a) B. M. Cossairt, N. A. Piro, C. C. Cummins, Chem. Rev. 2010, 110, 4164-4177; b) M. Caporali, L. Gonsalvi, A. Rossin, M. Peruzzini, Chem. Rev. 2010, 110, 4178-4235; c) M. Scheer, G. Balázs, A. Seitz, Chem. Rev. 2010, 110, 4236-4256; d) S. Khan, S. S. Sen, H. W. Roesky, Chem. Commun. 2012, 48, 2169-2179; e) W. Huang, P. L. Diaconescu, Chem. Commun. 2012, 48, $2216-$ 2218.

[8] V. Nesterov, D. Reiter, P. Bag, P. Frisch, R. Holzner, A. Porzel, S. Inoue, Chem. Rev. 2018, 118, 9678-9842.

[9] a) J. D. Masuda, W. W. Schoeller, B. Donnadieu, G. Bertrand, Angew. Chem. Int. Ed. 2007, 46, 7052-7055; Angew. Chem. 2007, 119, 7182-7185; b) O. Back, G. Kuchenbeiser, B. Donnadieu, G. Bertrand, Angew. Chem. Int. Ed. 2009, 48, 5530-5533; Angew. Chem. 2009, 121, 5638-5641.

[10] J. D. Masuda, W. W. Schoeller, B. Donnadieu, G. Bertrand, J. Am. Chem. Soc. 2007, 129, 14180-14181.

[11] a) A. J. Arduengo, J. C. Calabrese, A. H. Cowley, H. V. R. Dias, J. R. Goerlich, W. J. Marshall, B. Riegel, Inorg. Chem. 1997, 36, 2151-2158; b) A. Hinz, A. Schulz, A. Villinger, Chem. Commun. 2016, 52, 6328-6331; c) M. Cicač-Hudi, J. Bender, S. H. Schlindwein, M. Bispinghoff, M. Nieger, H. Grützmacher, D. Gudat, Eur. J. Inorg. Chem. 2016, 649-658; d) J. E. Borger, A. W. Ehlers, M. Lutz, J. C. Slootweg, K. Lammertsma, Angew. Chem. Int. Ed. 2017, 56, 285-290; Angew. Chem. 2017, 129, 291 296; e) M. H. Holthausen, S. K. Surmiak, P. Jerabek, G. Frenking, J. J. Weigand, Angew. Chem. Int. Ed. 2013, 52, 11078-11082; Angew. Chem. 2013, 125, 11284-11288.

[12] F. Dielmann, A. Timoshkin, M. Piesch, G. Balázs, M. Scheer, Angew. Chem. Int. Ed. 2017, 56, 1671-1675; Angew. Chem. 2017, 129, $1693-1698$.

[13] M. Piesch, M. Seidl, M. Stubenhofer, M. Scheer, Chem. Eur. J. 2019, 25, 6311-6316.

[14] C. Chan, A. E. Carpenter, M. Gembicky, C. E. Moore, A. L. Rheingold, J. S. Figueroa, Organometallics 2019, 38, 1436-1444. 
[15] O. J. Scherer, J. Schwalb, G. Wolmershäuser, W. Kaim, R. Gross, Angew. Chem. Int. Ed. Engl. 1986, 25, 363-364; Angew. Chem. 1986, 98, 349-350.

[16] a) T. Krachko, J. C. Slootweg, Eur. J. Inorg. Chem. 2018, $2734-$ 2754; b) K. Schwedtmann, G. Zanoni, J. J. Weigand, Chem. Asian J. 2018, 13, 1388-1405.

[17] G. Märkl, F. Lieb, Tetrahedron Lett. 1967, 8, 3489-3493.

[18] B. D. Ellis, C. A. Dyker, A. Decken, C. L. B. Macdonald, Chem. Commun. 2005, 1965-1967.

[19] a) M. Herberhold, G. Frohmader, W. Milius, Phosphorus Sulfur Silicon Relat. Elem. 1994, 93-94, 205-208; b) M. Herberhold, G. Frohmader, W. Milius, J. Organomet. Chem. 1996, 522, 185 196; c) B. Pinter, K. T. Smith, M. Kamitani, E. M. Zolnhofer, B. L. Tran, S. Fortier, M. Pink, G. Wu, B. C. Manor, K. Meyer, M. Baik, D. J. Mindiola, J. Am. Chem. Soc. 2015, 137, 15247-15261.

[20] P. Pyykkö, M. Atsumi, Chem. Eur. J. 2009, 15, 186-197.

[21] a) A. Doddi, D. Bockfeld, T. Bannenberg, P. G. Jones, M. Tamm, Angew. Chem. Int. Ed. 2014, 53, 13568-13572; Angew. Chem. 2014, 126, 13786-13790; b) M. Bispinghoff, A. M. Tondreau, H.
Grützmacher, C. A. Faradji, P. G. Pringle, Dalton Trans. 2016, 45, 5999-6003; c) M. Peters, A. Doddi, T. Bannenberg, M. Freytag, P. G. Jones, M. Tamm, Inorg. Chem. 2017, 56, 10785-10793; d) O. Lemp, M. Balmer, K. Reiter, F. Weigend, C. von Hänisch, Chem. Commun. 2017, 53, 7620-7623; e) G. Hierlmeier, A. Hinz, R. Wolf, J. M. Goicoechea, Angew. Chem. Int. Ed. 2018, 57, 431-436; Angew. Chem. 2018, 130, 439-444.

[22] CCDC CCDC-1938034 (2), CCDC-1938035 (4a), CCDC1938036 (4b), CCDC-1938037 (6/7) and CCDC-1938038 (8), contain the supplementary crystallographic data for this paper. These data are provided free of charge by The Cambridge Crystallographic Data Centre.

Manuscript received: July 6, 2019

Revised manuscript received: September 2, 2019

Accepted manuscript online: September 5, 2019

Version of record online: October 1, 2019 